\title{
MOVIMENTOS SOCIAIS NO BRASIL
}

\author{
Lúcio Flávio Rodrigues de Almeida
}

Eu queria agradecer, por mais essa oportunidade, à Universidade Estadual de Londrina. O prazer é muito grande em vir aqui e encontrar uma platéia atenta e interessada.

Vou tentar colocar algumas questões de caráter bastante polêmico, vou tentar fazer o melhor possível para que essa exposição suscite algum debate, de modo que saiamos daqui pelo menos com mais dúvidas e, talvez, algumas pistas de investigação acerca do tema que nos traz aqui esta noite, ou seja, a questão dos movimentos sociais.

A temática dos movimentos sociais tem uma longa trajetória, uma longa história, sobre a qual eu não vou me deter. Trata-se de uma questão bastante estudada e, em geral, de maneira bastante polêmica. Eu não vou traçar uma trajetória dos debates acerca dos movimentos sociais, mas eu gostaria de trabalhar em dois planos: no primeiro, expor aquilo que eu considero relevante acerca da análise dos movimentos sociais e, no segundo, realizar uma certa avaliação das análises feitas por outros autores sobre os movimentos sociais. Eu vou tentar trabalhar então com esses dois planos, e tentar, digamos assim, articulá-los.

Obviamente, quando abordamos os movimentos sociais estamos nos referindo a uma certa concepção que temos da sociedade. Torna-se impossível falar sobre movimentos sociais sem, direta ou diretamente, explícita ou implicitamente, apresentar uma concepção mais geral de como se estruturam as relações sociais. Então, para não ficarmos nesta ambigüidade, vamos abordar algumas teses acerca da estruturação da sociedade capitalista e, em seguida, iremos refletir algumas teses sobre os movimentos sociais.

Primeira tese, extremamente importante: conceituar a sociedade capitalista a partir da noção de modo de produção. O que quero dizer com isso? Parece-me mais fecundo pensar a sociedade capitalista não tomando apenas a sua dimensão econômica, mas tentando apreender o modo de produção capitalista como constituído por uma série de relações 
sociais que não são apenas econômicas, mas são também políticas e de caráter ideológico. Quando eu falo em capitalismo não penso apenas em economia, penso também em Estado e em ideologia. Quando penso em classes sociais, na sua constituição, e logo nas lutas de classe, já estão presentes não apenas a economia, como também a ideologia e o Estado. Dessa maneira, a análise fica muito mais rica e fecunda do que simplesmente tratar o capitalismo como um tipo de economia.

O que entendo por modo de produção capitalista? Entendo como modo de produção capitalista, fundamentalmente, de uma maneira esquemática, aquele modo de produção onde o trabalhador direto é duplamente separado dos meios de produção. O que quero dizer com isso? Quero dizer o seguinte: no modo de produção capitalista o trabalhador é um não-proprietário dos meios de produção. Por exemplo, o operário: este não é proprietário das máquinas, nem das matériasprimas, nem do prédio da fábrica onde ele trabalha. Nesse sentido, ele é separado pela relação de propriedade; ele não é proprietário dos meios de produção, e cada vez mais o operário não tem o controle do processo de trabalho.

Vamos pensar num operário atípico, um sapateiro: ele tem lá o seu ateliê, a sapataria; está meio sem sono agora, o time dele perdeu, está meio chateado; ele não vai dormir e resolve continuar a produzir artesanalmente uma bolsa que ficou de entregar na outra semana. Então, ele vai até a oficina, pega a agulha e a linha e começa a costurar a bolsa que ficou de fazer. Dessa forma, ele tem o controle do processo de seu trabalho; além disso, a bolsa vai ficar melhor ou pior dependendo da sua habilidade. Por outro lado, pensando agora num operário da Volkswagen: o time dele perdeu e ele está sem sono. Resolve, então, ir para a fábrica fazer um carro? Não vai. Primeiro, ele não tem a chave da fábrica; segundo, o processo de fabricação de um carro, um Gol, por exemplo, é um processo de trabalho coletivo, quer dizer, um operário só faz uma parte do carro e ponto final.

No fordismo tem-se uma linha de montagem onde cada movimento de um corresponde ao movimento de outros. E mesmo no chamado pós-fordismo, apesar de todas as mitologias acerca do toyotismo, por exemplo, o processo de produção industrial capitalista exige um trabalhador coletivo e cada vez mais coletivizado. Se tomarmos, por exemplo, a produção de uma lapiseira, como esta aqui, veremos que ela é produto de um trabalhador coletivo transnacional, o 
que implica furar poço de petróleo na Arábia Saudita, retirá-lo, refinálo, transportá-lo, transformá-lo em determinada resina, ao mesmo tempo que implica a produção de um determinado metal. Sabemos também que ela tem que ser montada e isso não acontece, necessariamente, na Arábia Saudita. Muito pelo contrário, os componentes são transportados até um determinado local onde isso aqui é montado e é completado o seu processo de produção.

Tudo isso implica uma separação no capitalismo, uma dupla separação do trabalhador, em relação aos meios de produção e ao produto dos processos de trabalho. Esse trabalhador tem, no capitalismo, uma peculiaridade em relação, por exemplo, ao servo da gleba. Quem já estudou o feudalismo nas suas linhas gerais sabe que o servo da gleba era um dependente do senhor feudal. O servo da gleba tinha mais autonomia para tocar a lavoura, tocar o trabalho agrícola no interior do feudo, mas social e juridicamente era um dependente do senhor feudal, não era dono do "próprio nariz", não era dono da própria vontade. O servo da gleba não era um sujeito jurídico pleno, era-o sim o nobre feudal. O servo era um dependente, uma espécie de não-emancipado.

É uma situação muito interessante, onde, no caso do feudalismo, o servo, o trabalhador direto, não era tão separado dos meios de produção, não era proprietário iminente, mas tinha um certo controle do processo de trabalho; entretanto, ele era dependente jurídica e politicamente. No capitalismo tem-se um processo exatamente oposto. Há uma separação total entre o trabalhador direto e os meios de produção. O operário não tem nem o controle dos processos de trabalho nem é proprietário dos meios de produção, mas, em contrapartida, é considerado um sujeito jurídico pleno, igual ao proprietário dos meios de produção.

Então, ao falarmos em capitalismo, estamos nos referindo à economia, ao direito, que é uma parte do Estado, ao sistema jurídico, à ideologia. Por quê? Porque onde o trabalhador direto tem acesso mais fácil aos meios de produção, ele, por incrível que pareça, tem que ser considerado inferior ao proprietário dos meios de produção. É por isso que no feudalismo jamais um servo poderia se tornar nobre. Era uma incongruência pensar dessa maneira. Ele nasceu servo, ele morrerá servo; o fosso entre o servo e o nobre era intransponível. Não havia, por exemplo, no feudalismo, muito lugar para uma idéia-força que é muito importante na sociedade moderna, que é aquela idéia dos direitos do 
homem, a idéia de que todos os homens são iguais, são essencialmente iguais.

Segundo a ideologia feudal, os seres humanos eram essencialmente desiguais. Eles poderiam ser secundariamente iguais, mas essencialmente eram desiguais. Na sociedade capitalista, pelo menos até agora, tem sido, em geral, exatamente o contrário, ou seja, o proprietário dos meios de produção e o trabalhador direto, o proletário, são considerados seres humanos essencialmente iguais e, ainda, a desigualdade e a diferença são consideradas secundárias — daí, por exemplo, a Declaração Universal dos Direitos do Homem considerar todos os seres humanos fundamentalmente iguais em direitos e deveres. Então, é uma situação muito interessante no capitalismo. O Estado burguês, vamos chamar assim, constitui a todos os membros da sociedade, sejam eles trabalhadores sejam proprietários dos meios de produção, como sendo juridicamente iguais, como sendo sujeitos.

É claro, se não houvesse esta constituição de todos como iguais não poderia haver a figura do contrato de trabalho. Vários autores já chamaram a atenção para isso: a idéia de que na nossa sociedade alguém contrata alguém, uma pessoa compra a força de trabalho e a outra a vende. Tal negociação, de compra e venda, é regulada por um contrato. Isso quer dizer que quem compra, compra porque quer e paga o preço que julga conveniente, e quem vende, vende porque quer vender, e recebe o preço que julga interessante receber. Então a sociedade moderna é apresentada como uma sociedade de indivíduos, como um aglomerado. Principalmente com o neoliberalismo isso voltou à tona: um aglomerado de indivíduos livres e iguais.

Quem pegou esta formulação ideológica e a levou às últimas consequiências foi aquela senhora que se tornou a primeira-ministra da Inglaterra durante um bom tempo, Margareth Thatcher, que afirmou o seguinte: "para mim não existe sociedade, para mim existem apenas indivíduos". Faltou ela completar que os indivíduos, tal como imagina, são essencialmente competitivos, que é a idéia da sociedade como mercado onde todos agem racionalmente, cada um querendo maximizar os seus benefícios, ou seja, conseguir o máximo de benefícios com o mínimo de investimentos, com o mínimo de bens.

Os neoliberais mais radicais vêem a sociedade como mercado nas múltiplas dimensões, não só o mercado econômico, mas o mercado afetivo, quer dizer, até a amizade é calculada na base de uma relação de 
custo e benefício. É claro que essa é uma visão extremamente ideológica, mas é interessante porque ela é fundamental. Para que a sociedade capitalista se reproduza é necessário que o Estado e todo o aparato institucional existente se apresente para cada um de nós como essencialmente bom e nos apresente a todos como livres, de modo que possamos nos apresentar como livres compradores e vendedores de força de trabalho. É a idéia do contrato livre, ou seja, o aparato ideológico do Estado passa a idéia de que o proletário é livre. Entretanto, sabemos que o trabalho no capitalismo é compulsório: ou o sujeito trabalha ou ele morre de fome. Para se manter essa ideologia do trabalho livre é necessário que o Estado constitua, no plano jurídico, a todos nós como indivíduos livres e iguais. Não sei se eu estou conseguindo explicar, mas é a ideologia da igualdade que torna possível uma relação de exploração.

Vamos tentar entender por que se dá essa relação de exploração. Vamos pegar o outro lado, o outro elemento para explicitação do capitalismo: os meios de produção são transformados em capital, só que eles são propriedade privada. As fábricas não são de todo mundo. Existem aqueles que são proprietários da fábrica, mas não é só isso. Quem é proprietário de uma fábrica, utiliza aquela fábrica, ou seja, os meios de produção como capital, o que significa, de uma maneira bem elementar, que o capital é tudo aquilo que utilizo para conseguir mais capital. Existe um processo de autodesenvolvimento do capital que, no fundo, é um processo de acumulação de capital. Só faz sentido para mim, enquanto capitalista, investir 100 , se eu puder obter o retorno de mais de 100. É por isso que eu sou capitalista, porque se eu investir 100 para obter menos de 100 , eu me suicido enquanto capitalista e um outro capitalista ocupa o meu lugar. O capital é capital na medida em que a sua entrada em movimento gere mais capital, e aí tem-se um fenômeno complicadíssimo e trágico na sociedade capitalista, ou seja, há momentos em que o investimento de capital na produção não gera mais capital, sendo melhor, nestes momentos, não investir capital na produção. Caso isso ocorra, temos um fenômeno fantástico que, se um marciano ou um índio observarem, não vão entender, ou seja, milhões de pessoas, como acontece no Brasil hoje, passam fome, milhões de pessoas "não têm camisa" - descamisados, como dizia o antigo presidente Collor ou o Peron na Argentina —, e as fábricas de camisa estão paradas. Agora, por que raios não se fabrica camisa até que o último descamisado esteja

Rev. Mediações, Londrina, v. 5, n. 1, p. 41-63, jan./jun. 2000 
vestido? Por que não se fabrica tênis ou sapato até que o último descalço não esteja mais com os pés gelando? Por que não se constroem casas, que é tão fácil construir, até que o último sem-teto esteja abrigado? Por um motivo muito simples: porque isso dá menos lucro do que você aplicar na produção de chicletes. É isso que explica porque determinados países têm mais de 100 marcas de chicletes e não têm casa para desabrigado morar; é isso que explica porque determinados países têm não sei quantas marcas de cigarro e não há sapato para todas as crianças deixarem de andar descalças e ao relento. Dito de outra forma: o setor de cigarros pode ser eventualmente mais rentável para o capital do que o setor de calçados para consumo popular.

As consequiências disso, no capitalismo, são visíveis. Na Grande São Paulo, já existe hoje cerca de 1,7 milhão de desempregados, e a fome se alastra, alastra-se a criminalidade, cresce a falta de auto-estima, avoluma-se a violência (muitas vezes gratuita), é gritante a falta de perspectiva de vida, e as fábricas vão fechando. Se a gente pegar, no caso do Brasil, de 1989 a 1996, mais de 33\% dos postos de trabalho foram eliminados, o que significa o seguinte: ao se eliminar um posto de trabalho, aquele que trabalhava ali ficou desempregado e ninguém ocupa o seu lugar, porque aquele trabalho não existe mais. Esse processo tem se acentuado de 1996 para cá, até porque, com o incremento da produtividade, todo mundo sabe disso, produz-se cada vez mais com menos trabalhadores. Então você tem essa situação trágica, que é o aumento gigantesco do desemprego, de um lado, e uma concentração de pobreza imensa, de outro.

O capitalismo não tem a finalidade de atender as necessidades humanas, ele é uma fantástica engrenagem de acumulação de capital. O Estado, no capitalismo, não pode explicitar isso, pois ele se apresenta como representante do bem comum, ou melhor, como representante de uma comunidade de cidadãos. O Estado capitalista, exatamente para poder organizar a dominação de classes, ocupa seu caráter classista apresentando-se como Estado nacional, como responsável pelo bem comum, pelo interesse geral da sociedade, como dando prioridade aos interesses dos mais pobres, aos interesses dos mais desvalidos. Essa é a ideologia fundamental que vigora na sociedade capitalista. É por isso que eu prefiro falar de capitalismo neste sentido mais amplo, pegando não só a dimensão econômica, mas também a esfera jurídica, política, ou seja, a esfera estatal, o Estado e as leis, e também a ideologia. A 
ideologia, no capitalismo, nos apresenta não como membros de uma classe, ou proletários, ou classe média, ou burguesa; ela nos apresenta como cidadãos, eventualmente como consumidores. Ora, se isso faz sentido, nós temos uma categoria ideológica central para a reprodução do capitalismo, que é a categoria de cidadão. Ou seja, o capitalismo nos apresenta a todos como cidadãos e não é à toa que a Declaração dos Direitos do Homem e do Cidadão é fruto da revolução burguesa.

Por que todo esse preâmbulo? Entendendo melhor as categorias da formação social capitalista, podemos falar de movimentos sociais. Dito de outra forma, na trajetória dos movimentos sociais - eu vou pegar os últimos vinte anos dos movimentos sociais no Brasil de uma maneira panorâmica, se for necessário eu recuo um pouco mais no tempo - ficou mais ou menos consagrada uma tese que tem algumas implicações. É a seguinte: muitos teóricos e estudiosos dos movimentos sociais no Brasil costumam afirmar que, numa primeira etapa dos movimentos sociais, dos chamados "novos" movimentos sociais depois eu quero discutir essa idéia de "novos" movimentos sociais quando eclodiram, por volta dos anos 70 , eram movimentos que estavam na sua infância, eram ainda imaturos e tinham como adversário principal o Estado. Naquela época, inclusive, essa idéia de movimentos sociais em contraposição ao Estado era uma idéia muito elaborada por vários teóricos dos movimentos sociais. Com o passar do tempo, como tudo na vida, os movimentos sociais teriam amadurecido, e agora, nos anos 90, esses movimentos sociais teriam, ao amadurecer, mudado a sua posição em relação ao Estado, ou seja, deixaram de tê-lo como adversário e passaram a considerá-lo como interlocutor. Alguns autores inclusive usam a palavra parceria, querendo dizer com isso que, ao amadurecerem, eles passaram a ver no Estado mais um parceiro com o qual deveriam atuar do que um adversário contra o qual deveriam lutar. Sobre isso escreveram - deixa eu citar pelo menos duas autoras - Ruth Cardoso, que tem um texto muito famoso sobre a trajetória dos movimentos sociais em que faz exatamente esse balanço, e Eunice Durhan, que também escreveu um texto muito importante, uma análise competente, muito bem preparada, dos movimentos sociais; entretanto, adota também esse balanço.

Uma implicação dessa tese, que eu pretendo criticar, é a afirmação de que os "novos" movimentos sociais lutavam fundamentalmente pela cidadania. Essa luta pela cidadania é vista, em geral, como luta pela 
cidadania mesmo, por aqueles que não eram cidadãos, ou luta pela ampliação, pela expansão da cidadania. Na minha avaliação, esse tipo de análise contém uma série de mal-entendidos, como acabei de mencionar no início de minha fala.

Em primeiro lugar, esta relação com o Estado parece ser abordada de uma maneira abusivamente genérica, ou seja, determinados movimentos sociais, de fato, têm uma relação menos antagônica com o Estado. Em geral são movimentos que têm objetivos mais específicos e podem ser atendidos pelo Estado sem que isso implique grandes transformações na estrutura social. Outros movimentos sociais têm uma relação mais tensa, ou até uma relação mais antagônica para com o Estado, não porque eles sejam mal-humorados ou porque eles não gostem do Estado, mas porque os objetivos pelos quais eles lutam colidem, entram em choque com a ordem estabelecida, e a função do Estado não é atender a qualquer movimento social. A função fundamental do Estado é, apesar da ideologia dominante, assegurar as condições políticas e jurídicas da dominação de classe e, no caso do capitalismo, da dominação capitalista de classe. A ideologia dominante é que afirma que o Estado tem por finalidade zelar pelo bem comum, mas uma coisa é o que a ideologia dominante afirma sobre o Estado e, uma outra, é o que o Estado faz efetivamente: se a função dele fosse zelar pelo bem comum, nós não teríamos 65 milhões de pobres indigentes. Nunca é realizado um esforço do Estado para resolver esse problema, ao mesmo tempo em que o grande capital bancário é socorrido ao primeiro sinal de perigo. Exemplos para isso não faltam.

Nós temos na direção do Banco Central um personagem ligado a uma grande empresa especuladora que atua em escala planetária. Temos, na direção do Estado brasileiro, um pessoal quase todo voltado para os interesses do grande capital, seja capital brasileiro, nativo, seja capital transnacional. Nós temos no Congresso Nacional uma sobrerepresentação dos empresários, que são minoria na sociedade, e uma sub-representação dos trabalhadores, que são maioria na sociedade. Certa vez saiu uma matéria na Veja - que não é uma revista exatamente de esquerda - mostrando o partido dos banqueiros no Congresso Nacional; embora não exista legalmente, existem muitos parlamentares que são eleitos com financiamento da Febraban (Federação Brasileira dos Bancos). Este número de parlamentares é maior do que o número de parlamentares eleitos pela legenda do PT e do PDT juntas. Caso se 
somem os deputados e senadores de ambas as legendas, não vai dar o número de senadores e deputados eleitos pelos banqueiros no Brasil, ou seja, o partido informal dos banqueiros é um grande partido, o que significa que no Parlamento e no Executivo uma minoria da população brasileira tem uma representação maior e a maioria da população brasileira tem uma representação menor. Há um clichê que é muito usado, que atenta o seguinte: cada sociedade tem o Congresso que merece, ou, ainda, o Congresso é o retrato da sociedade brasileira, é o reflexo dela. Eu costumo dizer que não, pois eu vejo que o retrato, no caso uma reprodução da sociedade brasileira, é mais encontrado nas prisões, porque nelas há uma maioria de pobres e uma minoria de ricos. No Congresso encontramos uma representação invertida da sociedade brasileira, ou seja, uma maioria de ricos e uma minoria de pobres.

Voltando à discussão, nós perguntamos: que negócio é esse de movimento social lutar pela cidadania? Penso que aí há uma outra confusão que considero importante instigar para a reflexão e o debate. Essa confusão começa com o próprio uso do termo "novo". A partir dos anos 70 era muito comum falar em "novos" movimentos sociais e, como no Brasil, em geral, qualquer coisa para pegar tem que passar pelo exterior, quer dizer, primeiro o filme tem que disputar o Oscar para acharmos o filme bonito aqui no Brasil, porque senão ele passa desapercebido — só depois que ele se candidata fica bonito —, a mesma coisa acontece com algumas noções, no caso, a idéia de "novos". Será que estamos trabalhando com o mesmo objeto de pesquisa? Sabemos, entretanto, que a maioria dos teóricos dos "novos" movimentos sociais é constituída por teóricos estrangeiros, em geral norte-americanos e europeus. Na Europa, teóricos franceses, como o Alain Touraine. Em todo caso, quando Touraine, e também uma grande quantidade de teóricos europeus e norte-americanos, falavam em "novos" movimentos sociais, se referiam aos movimentos que atuavam principalmente na esfera dos costumes, da ética comportamental. Aquelas sociedades que esses teóricos costumavam designar pela expressão sociedades pósindustriais eram sociedades que já teriam deixado para trás as lutas típicas da chamada sociedade industrial, por exemplo, as lutas entre trabalhadores e capitalistas; aí então se lutava por um novo modo de vida, por novos comportamentos; havia lutas de caráter ecológico, lutas de mulheres, lutas feministas - inclusive para que a mulher tivesse mais controle da sua sexualidade, tivesse o controle do seu corpo, 
pudesse ter liberdade de movimentos da mesma forma que os homens, pudessem ser respeitadas no seu ir e vir fora do espaço doméstico etc. Nessa mesma época, no Brasil, os movimentos sociais foram chamados "novos"; entretanto, eles não eram exatamente assim.

O início dos anos 70, no Brasil, em primeiro lugar não tem nada de sociedade pós-industrial, nem para aqueles que, na Europa central ou nos Estados Unidos, falavam em sociedade pós-industrial; o que havia no Brasil nos anos 70, de mais significativo do ponto de vista das relações de produção, era o chamado "milagre brasileiro". Tratava-se de um acelerado desenvolvimento industrial, que começa mais ou menos em 1969 e vai mais ou menos até 1973. Então, no Brasil o que estava havendo não era a superação do fordismo, pelo contrário, era uma nova onda de constituição do chamado padrão taylorista-fordista, com grandes forças de acumulação sob uma ditadura militar. O que ocorria aqui era um aumento acelerado da classe operária fordista e a expressão maior disso foi a industrialização do $\mathrm{ABC}$ paulista, como São Bernardo, Santo André, Diadema, com a grande indústria automobilística empregando muitos operários, não só pelas montadoras, mas por aquele colar de indústrias de autopeças que produzia em função dessas montadoras de veículos.

Como podemos notar, a realidade brasileira era bem diferente da realidade norte-americana ou francesa, onde, por exemplo, Touraine falava dos chamados "novos" movimentos sociais; aqui, porém, estava havendo um aumento da classe operária, um crescimento do parque industrial fordista. Ainda, nesse contexto, encontramos um aumento do êxodo rural, pessoas que saíam das relações de um mundo agrário ainda muito marcado pela dependência pessoal. Dessas pessoas, aquelas que tinham mais sorte entravam direto no novo mundo marcado pela relação entre capital e trabalho na grande indústria, e outras, com menos sorte ou menos qualificação, iam trabalhar na construção civil, ficando na periferia dessa nova onda de avanço capitalista, o chamado "milagre brasileiro", ocorrida no início dos anos 70 .

Ora, quais serão as bandeiras de luta dessa população? Aqueles que se inseriam na grande indústria, no setor de ponta da indústria brasileira, vão lutar por melhores salários, por melhores condições de trabalho, vão constituir sindicatos, o que era muito perigoso naquela época. Enquanto nesse mundo dos "novos" movimentos sociais, na França por exemplo, a vida sindical está minguando e a vida política está arrefecendo, no Brasil está acontecendo o contrário. A partir de 
1978 você tem uma onda de greves que fascina o mundo, com assembléias de $80 \mathrm{mil}$ trabalhadores - alguns dos presentes aqui chegaram a presenciar estes acontecimentos, por exemplo, no Estádio da Vila Euclides, em São Bernardo do Campo, quando o Lula se torna uma figura mundialmente conhecida. O que estava havendo era uma retomada das lutas sindicais no Brasil, no contra-fluxo do que estava acontecendo no resto do mundo -- exceto na Polônia, com o movimento Solidariedade, que também estava crescendo, liderado por Lech Walesa, que vai dar numa outra direção.

Segunda diferença: esse "novo" movimento operário no Brasil vai dar origem a uma forte central sindical, a Central Única dos Trabalhados - sobre a qual hoje podemos fazer as críticas que quisermos, mas naquela época era extremamente combativa e tinha, inclusive, propostas de transformação socialista da sociedade entre alguns de seus dirigentes, isto num momento em que as taxas de sindicalização estavam diminuindo no mundo todo e em que os sindicatos estavam sendo enfraquecidos. Mas, mais ainda, este movimento operário vai estar na origem de um aguerrido Partido dos Trabalhadores que vai crescendo e liderando lutas, inclusive com a plataforma de transformação socialista adotada por algumas direções deste partido, em uma época em que a onda no mundo todo, ou quase todo, era de declínio da atividade políticopartidária, principalmente de partido operário. Numa época em que os partidos socialistas e comunistas estavam em declínio, no Brasil estava acontecendo exatamente o contrário, ou seja, havia uma elevação da atividade sindical e da atividade partidária, e o efeito mais notável disso foi a candidatura do Lula a presidente da República contra o Collor, chegando quase a vencer as eleições. Esse parece ter sido o grande momento, talvez o ápice, o auge desse processo que começa no Brasil, ao longo dos anos 70 , na virada dos anos 70 para os anos 80 . Tudo isso ocorria no núcleo mais avançado do desenvolvimento capitalista no Brasil, ainda em padrões fordistas. Portanto, falar em sociedade pósindustrial no Brasil naquele momento era realmente uma importação de conceitos totalmente abusivos. Isto não quer dizer que todo mundo foi trabalhar na indústria automotiva do $\mathrm{ABC}$. Temos um processo de proletarização que é muito mais amplo, até porque o sentido de proletarização é duplo e é contraditório.

Podemos, a partir de agora, fazer uma reflexão sobre o processo de proletarização no Brasil, ainda que de forma esquemática, mas que 
serve ao nosso debate. A proletarização tem, pelo menos, dois sentidos, e um se contrapõe ao outro: primeiro, significa a transformação do proprietário em não-proprietário, ou seja, desapropriação. $\mathrm{O}$ desenvolvimento do capitalismo transforma cada vez mais os proprietários em nãoproprietários dos meios de produção. Há um processo de proletarização nesse sentido - o do campesinato, por exemplo. Basta lermos aquele livro Era dos extremos, do Hobsbawm, em que ele explica uma das grandes novidades do século XX, que é a extinção do campesinato. Tenho a impressão de que ele exagera um pouquinho, mas, de fato, o nível de expropriação do campesinato no mundo todo é tão grande que hoje grande parte da humanidade, em qualquer ponto do planeta, é constituída de seres humanos separados dos meios de produção, ou seja, não-proprietários dos meios de produção. Por isso, temos cada vez mais milhões e milhões de seres humanos que não são proprietários dos meios de produção, não são proprietários de loja — se bem que loja não seja exatamente um meio de produção - nem de fábricas, nem de oficinas artesanais, nem de fazendas. Eles são expropriados dos meios de produção.

Em segundo lugar, a proletarização pode ser entendida num sentido mais estrito, que é de inserção direta desses expropriados no processo de produção industrial, segundo as relações de produção capitalista. E aí é evidente que os dois sentidos não batem: os proletarizados no primeiro sentido são muito mais numerosos do que os proletarizados no segundo sentido. Constatamos isso ao observar os índices de desemprego: o proletariado em sentido amplo, ou seja, o conjunto daqueles que não são proprietários dos meios de produção, é muito maior do que o número dos proletários em sentido estrito, ou seja, daqueles que trabalham diretamente na indústria segundo padrões de produção em qualquer lugar do mundo. Aliás, estes proletários industriais, no momento, estão até diminuindo, se bem que há um grande debate sobre isso. Agora, os proletários num sentido amplo, ou seja, os expropriados dos meios de produção, estão aumentando cada vez mais, até porque a concentração da propriedade dos meios de produção é cada vez maior.

Ora, como trabalhar com isso à luz de uma análise dos movimentos sociais? Em primeiro lugar, não é fatal, não está escrito no crachá de nenhum membro de movimento social que necessariamente ele está lutando pela cidadania; não está no código genético de nenhum 
movimento social que ele nasceu para lutar pela cidadania. A meu ver, isto é coisa de intelectual que quer domesticar o movimento social, porque, para eles, enquanto estes movimentos estiverem lutando por cidadania está bom, mas se ultrapassarem esta bandeira deixarão de ser movimento social. Tais intelectuais agem como se estivessem tirando da cabeça deles um código de conduta para os movimentos sociais, quando, na verdade, diferentes movimentos sociais, de acordo com o seu perfil ideológico, de acordo com a correlação de forças política, econômica e inclusive ideológica, podem lutar por diferentes objetivos. Há movimentos sociais que podem lutar pelo socialismo também, a menos que Touraine proíba, que ele escreva um livro, como já escreveu, é só ler o Crítica da modernidade ou os seus últimos livros, que são cada vez menos teóricos, menos explicativos e cada vez mais normativos - e isso aconteceu com grande parte das ciências sociais no Brasil também. Uma grande parte dos estudiosos dos movimentos sociais, ao invés de escrever uma análise elaborada, acaba escrevendo normas de condutas, explicando aos movimentos sociais como eles devem se comportar, e aí eu citaria, por exemplo, formulações do tipo "os movimentos sociais amadureceram".

Mas, segundo qual critério eles amadureceram? A resposta que esses intelectuais vão dar é que os movimentos sociais deixaram de lutar contra a ordem estabelecida porque passaram a lutar pela cidadania. Não compreendo por que lutar por água, luz e creche é lutar pela cidadania. Esta relação não está clara. Sendo assim, proponho um modelo alternativo de análise: esse grande proletariado, em sentido amplo, tem lutas específicas e formas de organização que não são contempladas, muitas vezes, pelo proletariado em sentido estrito. O proletariado em sentido estrito, o proletariado industrial tal como se constituiu no século $\mathrm{XX}$, acabou adotando determinadas características como, por exemplo, as do chamado proletariado fordista, que outros chamam proletariado social-democrata, termo que eu acho meio exagerado para o Brasil, por ser constituído fundamentalmente por operários do sexo masculino em geral, as mulheres trabalham em setores muito particulares, ganhando menos e têm a chamada dupla jornada de trabalho. Esse proletariado constituiu organizações de luta sindical e política extremamente patriarcais. Os seus sindicatos, grandes sindicatos, tinham, normalmente, nos seus mais altos cargos, indivíduos do sexo masculino, e os grandes partidos políticos de base operária também tinham, nas suas principais 
lideranças, indivíduos do sexo masculino. As plataformas de luta desses movimentos, seja na expressão sindical, seja na expressão partidária, eram plataformas que contemplavam tais características, deixando em segundo plano as bandeiras de luta que eram consideradas extrínsecas ao movimento operário como, por exemplo, a luta por creche, água e luz, transporte coletivo etc.

Desde os anos 70 temos, no Brasil, a intensificação do imenso movimento de proletarização em sentido amplo também e, portanto, não ocorre somente a proletarização em sentido restrito, na medida em que uma quantidade imensa de pessoas que trabalhavam no campo é expulsa de lá — algumas continuam trabalhando no campo, mas agora sob novas relações de trabalho: são os proletários rurais, os bóias-frias - e tenta se inserir na periferia das pequenas, médias e grandes cidades. Trata-se de uma inserção extremamente precária, pois vão morar em favelas, em bairros recém-construídos, sem nenhuma estrutura urbana. E esses setores do proletariado que não estão organizados em grandes sindicatos, que não estão organizados em grandes partidos, vão lutar por objetivos que são fundamentais para eles e que não estão entre os objetivos consagrados pelo movimento operário já bem estruturado. Que objetivos são esses? Por exemplo, lutar por creche, lutar por condições mínimas para que as mulheres possam trabalhar fora de casa, lutar por água e luz, lutar por iluminação nos bairros onde moram, todos requisitos elementares para a defesa das condições de vida dessa parte, desse amplo proletariado que estava se constituindo naquele momento. Estou falando esquematicamente, porque houve casos, e existem até hoje, de proletários em sentido estrito, mesmo no $\mathrm{ABC}$ paulista, morarem em favela, mas vamos deixar esses casos mais mesclados, embora muito importantes; vamos trabalhar com casos mais esquemáticos, para facilitar a discussão. Quem me garante que essas lutas que começam relativamente radicalizadas, reivindicando condições mínimas de sobrevivência, eram lutas pela cidadania? Essas lutas não tinham a possibilidade de ser articuladas a outras lutas que questionavam a estrutura da sociedade brasileira, porque essas lutas, na medida em que chegaram a ver o Estado como algo não muito confiável, eram imaturas e porque depois, quando elas arrefeceram, tornaram-se maduras. Não posso considerar, por exemplo, que o movimento social, ao abandonar a sua perspectiva de transformação social e aderir à luta pela cidadania, não sofreu uma derrota ideológica. Por que não posso considerar que esse movimento 
sofreu uma derrota política? Em outra linha de raciocínio, deveria considerar necessariamente que ele amadureceu. Ora, o que para uns é amadurecimento, para outros pode ser uma derrota; o que para uns é pragmatismo, senso prático, para outros pode ser um enquadramento, pode ser uma domesticação.

Não sei se está mais ou menos claro, mas estou tentando colocar o seguinte: na análise dos movimentos sociais existe ideologia, como na minha análise também existe, quer dizer, não estou aqui me apresentando como alguém não-ideológico, como Durkheim gostava de apresentar a sua ciência. Também não me apresento aqui como alguém que traz a ciência contra a ideologia de todo mundo. A diferença é que existem diferentes perspectivas ideológicas, que orientam diferentes análises da realidade social. Então, o mais interessante é que cada analista explicite qual é a sua perspectiva, ou seja, de que lugar ele fala, quais são os valores e quais são as perspectivas teóricas que orientam a sua análise - aí fica mais fácil a interlocução, ficando mais difícil você colocar um "selinho" ISO 9002: "esse movimento é maduro", "esse movimento não é maduro mas vai chegar lá, vamos dar um tempinho que ele vai ficar maduro e vai lutar pela cidadania". Agindo assim, estou antes projetando na realidade aquilo que eu desejo que a realidade deva ser que estudando, com o mínimo de objetividade, como aquele movimento social de fato surgiu, como ele se desenrolou, como ele chegou a um determinado termo, como tudo na vida.

Qual é o grande equívoco daquelas análises teóricas que identificavam os "novos" movimentos sociais? Poderíamos pensar em dois: em primeiro lugar, quando se afirmou pela academia toda que os movimentos sociais finalmente tinham chegado à maturidade e a luta a partir de então era no campo da cidadania.

É possível identificarmos hoje dois grandes movimentos sociais que contestam aquelas análises teóricas que procuravam rotular os estágios de maturidade dos movimentos sociais. Para ficar apenas na América Latina, podemos citar o Exército Zapatista de Libertação Nacional, no México, liderado pelo subcomandante Marcos, que resiste às intervenções do Estado mexicano graças à extrema radicalidade que esse movimento adquiriu e à solidariedade internacional que recebeu. Outro movimento social de envergadura é o Movimento dos Trabalhadores Sem-Terra (MST), no Brasil, que fala em cidadania mas não abriu mão de formas de luta extremamente diretas e conseguiu impor 
algumas derrotas à política neoliberal do governo brasileiro. Sabemos, portanto, que a eles não se aplica a maioria das análises que foram feitas sobre os movimentos sociais e que acabaram tendo uma espécie de consagração no mundo acadêmico.

A título de provocação, eu diria basicamente o seguinte: alguns movimentos sociais lutam pela cidadania, sim e não. Todo Estado capitalista procura, na medida em que não consegue reprimir todas as lutas, domesticá-las, enquadrá-las, e a melhor maneira de enquadrar um movimento social qualquer é atribuir a esse movimento o objetivo de luta pela cidadania. Afinal de contas, ser cidadão é muito bom, ninguém está dizendo o que que todos devem ser como cidadãos, mas num país como o Brasil, a luta por cidadania já é muito importante, dependendo do modo como ela é levada. Entretanto, a noção de cidadania implica lealdade ao Estado nacional, ela não é em si subversiva, embora ela seja subversiva no escravismo, pois o escravo não pode ser cidadão. A noção de cidadania é estruturalmente subversiva no feudalismo, uma vez que o servo não é cidadão, mas ela não é subversiva no capitalismo. O operário é cidadão. Aliás, é exatamente porque ele é cidadão que pode fazer um contrato de trabalho; e se não fosse cidadão seria um dependente, e aí não daria nem para dizer que ele é um cidadão livre. A cidadania civil tem sido um requisito essencial para reprodução da sociedade capitalista, então, o movimento social, não necessariamente luta pela cidadania. Atribuir esse objetivo a todos os movimentos sociais é um equívoco.

Em segundo lugar, quando elegeram o Estado não como adversário, mas como parceiro ou interlocutor. Esta questão parece-me mal-formulada, porque, na verdade, dá a impressão de que o Estado está meio descolado dos proprietários dos meios de produção, ou seja, que ele é algo acima e além das classes sociais. Mas se eu adoto a concepção que me parece mais plausível teoricamente, de que o Estado no capitalismo organiza os interesses da classe dominante, e que ela não existe sem o Estado, então este não pode estar acima das classes, uma vez que ele organiza a dominação de uma classe sobre outra. Evidentemente que essa relação não deve ser examinada apenas no tocante aos movimentos sociais. Ela deve ser examinada no contexto das lutas de classes na sociedade capitalista. E aí é importante saber o seguinte: primeiro, qual é a composição de classe de cada movimento social e, segundo, se os objetivos daquele movimento social são ou não 
compatíveis com a reprodução da dominação capitalista de classe. Se eu vejo a questão dessa forma, verei o Estado não como prestador de serviço, mas como órgão que vai exatamente direcionar esses movimentos sociais, quaisquer que sejam eles, a objetivos-alvos que não colidam com a reprodução da dominação capitalista de classe; obviamente outros atores sociais e políticos vão tentar fazer exatamente o contrário, vão tentar direcionar as lutas dos movimentos sociais para uma transformação das relações capitalistas, seja no plano ideológico, seja no econômico, seja no político, e nesse sentido eles não vão ficar simplesmente na luta pela cidadania, embora possam passar por ela, ou seja, a própria idéia do que é movimento social e a própria idéia de quais são os objetivos dos movimentos sociais são idéias perpassadas por uma luta ideológica.

Como todos nós estamos inseridos socialmente, é obvio que as análises que nós fizermos e as práticas que nós encetarmos no que se refere aos movimentos sociais terão as marcas de nossa opção de vida, e terão a marca de nossas escolhas teóricas também. Então, nesse sentido, não existe análise, a meu ver, que seja ao mesmo tempo científica e ao mesmo tempo neutra acerca dos movimentos sociais.

Nos dias atuais, lutar pela cidadania implica no mínimo uma análise do processo de transnacionalização do capitalismo, ou seja, o capitalismo tem uma tendência também dupla e contraditória, a se nacionalizar e a se expandir para além das fronteiras nacionais. $\mathrm{O}$ processo é de contração e espraiamento do capitalismo, embora atualmente predomine o de espraiamento das relações capitalistas de produção. O capitalismo praticamente se planetarizou, é aquilo que chamam de uma maneira insuficiente e pobre de "globalização", mas onde eu quero chegar é no seguinte: o capitalismo hoje, nessa atual fase de transnacionalização, deixa o Estado nacional numa situação muito difícil, pois esse Estado nacional, pelo menos alguns, como é o caso do Estado brasileiro, tem uma capacidade de implementar políticas extremamente pequenas, uma elevação na taxa de juros do Banco Central norte-americano arrebenta com qualquer política implementada pelo governo brasileiro ou o governo argentino, que são extremamente frágeis para implementar políticas econômicas ou políticas sociais de qualquer tipo, o que não acontece obviamente com o governo norte-americano.

O que isso significa? Como podemos ver no jornal Folha de $S$. Paulo de hoje, saiu uma revista do PSDB, é a revista oficial do partido do presidente da República, que considera o desemprego como algo 
inevitável, porque não tem como eliminá-lo, pois para isso seria necessário mudar o capitalismo. Existe até um teórico do partido que afirma que eliminar o desemprego é impossível e que isso até que é bom, porque abre campo para que os desempregados se dediquem às atividades menos monótonas do que as daqueles que estão empregados. O desemprego abre um imenso espaço para a criatividade e, talvez com isso, algum de nós opte pelo desemprego. Quem sabe mais gente vai brigar agora, não por emprego, mas para ficar desempregado, para se livrar dessa entediante atividade, dessa monotonia de bater o ponto todo dia na entrada e na saída do trabalho.

Vemos assim a confissão de que o Estado brasileiro, já faz tempo, abriu mão de políticas que criem uma situação de, pelo menos, proximidade com o pleno emprego. Em outras palavras, é para se levar a sério aquela expressão usada pelo presidente de que existe os "inempregáveis", ou seja, aqueles que não vão conseguir emprego mesmo e ponto final. Do ponto de vista da democracia isso quer dizer que devemos aceitar a realidade de que milhões e milhões de pessoas estão condenadas ao desemprego, milhões e milhões de pessoas passarão fome e frio, milhões e milhões de pais chegarão em casa e não conseguirão olhar nos olhos de seus filhos porque não terão comida para levar para casa. Numa situação dessas para quem se preocupa com a dimensão ética da política, é ético convencer essas pessoas de que a democracia é um bom negócio? É ético chegar nessas pessoas e dizer vote em mim e aguarde mais tantos anos até as próximas eleições que a gente vai tentar ver se resolve a situação? Chega um ponto em que, numa situação dessas, convencer os movimentos sociais, principalmente os constituídos por pobres ou miseráveis, a se contentarem a depositar o voto nas urnas e passarem fome mais quatro anos, chega a ser eticamente imoral, eticamente condenável. O pior é que dificilmente essas pessoas se conformarão com a fome delas próprias e de seus filhos, a menos que elas sejam manipuladas, daí a extraordinária importância dos meios de comunicação que criam uma espécie de consumo virtual.

Um sociólogo muito importante, Boaventura de Souza Santos, fala muito nisso, quer dizer, existem pessoas que comem o "Big Mac" no outdoor. Fora isso, esses meios de comunicação criam um clima de prosperidade, pois o "visual do carro que não é seu mas está passando por você" cria uma certa situação de euforia de que em algum momento chegaremos lá; ou cria alguns ídolos populares que são idolatrados 
porque deram certo na vida. Então, cada vez mais tem-se essa situação nas grandes cidades, onde a ostentação é sinal de prestígio, onde muitas vezes o miserável é visto com um misto de inveja e admiração, e aí a ideologia é fundamental, na medida em que a ideologia do consumismo acaba criando uma espécie de conformismo. O poder dos meios de comunicação é tão grande que provoca no pobre a sensação de que a solução para a pobreza é sua individualmente, fazendo com que ele se descole do restante dos membros da sua classe. Mais ainda, ele assume os mesmos valores de consumo dos ricos, na medida em que ele vai tentar tomar o tênis ou o relógio de marca na esquina de uma grande metrópole como São Paulo.

Partindo desse ponto, discutir a questão da exclusão social começa a ficar bem complicada. O que é ser excluído e o que é ser incluído? Poderíamos dizer que, do ponto de vista ideológico, o "trombadão" que tenta tomar o relógio de 2 mil reais de alguém que está com um carro importado numa esquina de São Paulo compartilha dos mesmos valores consumistas desse que está sendo assaltado. Ambos para mim, do meu ponto de vista pessoal, são uns perfeitos idiotas, mas eu não estou aqui para julgar pessoas, estou aqui para ser um respeitável cientista social. Então vamos falar em sociologia: eles não são idiotas, eles compartilham dos mesmos valores, extremamente consumistas e competitivos, e são ainda extremamente fetichistas. Por quê? Porque eles acham que são as coisas que eles possuem, ou seja, sem o carro, sem o relógio de marca, ou a calça de marca, sem o tênis de marca, eles se sentem um joão-ninguém. Então, por isso, precisam usar tudo aquilo que, segundo o que é dito para eles, uma pessoa digna tem que usar para ser uma pessoa digna. Assim, eu não sei se dá para falar em exclusão social desse ponto de vista, pois ambos estão incluídos; e estão incluídos numa relação extremamente fetichizada, onde cada um é não aquilo que é pelo seu comportamento, mas pelos "penduricalhos" que carrega, pelos adereços que ostenta, pela grife que usam etc.

Agora do outro lado - por isso que eu gosto de falar de capitalismo tomando as várias dimensões das relações sociais —, do ponto de vista da produção, temos aqueles que estão incluídos, mas eu não tenho inveja deles não, porque está voltando o trabalho escravo. Na ponta da linha de produção de grandes empresas transnacionais existe trabalho escravo e existe trabalho familiar sobre a dominação do macho, ou seja, o chefe de família obrigando a mulher, supervisionando o seu trabalho 
e o dos filhos, isto é, exploração do trabalho infantil sob a supervisão do chefe da família, inclusive explorando padrões e costumes précapitalistas. A minha questão é a seguinte: isso é inclusão? Do ponto de vista do processo produtivo ele está incluído, até a criança está incluída. Mas não está incluído, por exemplo, do ponto de vista de uma inserção típica do capitalismo naquilo que ele produziu, o cidadão livre e, pelo menos juridicamente, igual. Então esse incluído é uma tragédia. De outro lado, o excluído compartilha dos mesmo valores do incluído, ou seja, é uma situação muito mais complexa. Nesse sentido, o que é ser cidadão? O escravo por definição não é cidadão, mas e condenado pelo desemprego é cidadão? Nós sabemos que o capitalismo está criando cada vez mais uma concentração de renda: no Brasil, por exemplo, $10 \%$ da população têm $50 \%$ da renda nacional, enquanto que $50 \%$ da população têm $10 \%$ da renda. Em outras palavras, podemos afirmar que é uma das piores distribuições de renda do planeta Terra.

O que é lutar pela cidadania numa situação dessas? Sabendo que estruturalmente o capitalismo está expelindo o trabalhador, está proletarizando no sentido amplo, mas não está proletarizando no sentido estrito, essas são as questões que eu trouxe para debate, dizendo que, apesar de todas as minhas críticas, eu me sinto extremamente otimista neste fim de século. Com a retomada de lutas coletivas e movimentos como o Movimento dos Trabalhadores Sem-Terra estão surgindo novas perspectivas de ação coletiva para milhões de brasileiros no campo e na cidade, a despeito de todas as suas contradições. O MST hoje apresenta alternativas de política sérias à criminalidade humana, que o governo Cardoso não consegue apresentar. E mais, o MST apresenta alternativas baratas de política educacional que o governo Fernando Henrique Cardoso é incapaz de apresentar; além de apresentar alternativas de solução do problema do menor abandonado que nenhum programa da Comunidade Solidária consegue apresentar. Nesse sentido, penso que nós, como cientistas sociais, como estudiosos da sociedade, temos o dever de estudar, de conhecer o mais profundamente e o mais vigorosamente possível a sociedade que nos propomos a estudar. Cientista que não estuda não é cientista. O nosso papel vai mais além, ou seja, não basta apenas conhecer a sociedade, é necessário ter em mente que aquilo que nós vemos tem a ver com aquilo que nós somos e fazemos. Por isso, o objetivo mais imediato de todos nós, preocupados com uma sociedade melhor, é denunciar qualquer tentativa de criminalização do 
MST. Isso não pode passar em branco. Jovens como aqueles que estão me ouvindo aqui não devem perder a oportunidade de ver com os próprios olhos o que se passa nos acampamentos do MST. Visitem os assentamentos e verifiquem a realidade deles com os próprios olhos. É um bom ponto de partida; com o conhecimento sensível, ele pode despertar a vontade do conhecimento científico. Além disso, vão e observem como seres humanos; como seres humanos inseridos numa certa posição na sociedade, vão e vejam aquilo, examinem se vale a pena tratar como criminosos pessoas que querem plantar para comer, para alimentar-se e para alimentar seus filhos. Num país que tem a maior extensão de terras aráveis do mundo, se não há lugar para sem-terra plantar, onde é que vai ter? Na Suíça, no México, nos Estados Unidos? Sabemos que tem mais terras aráveis aqui do que lá. O problema é que o Brasil, desde Pero Vaz de Caminha, não resolveu a questão agrária. Começou matando o índio, continuou matando sem-terra. Quando em 1850 foi abolido o tráfico de escravo, foi também adotada a Lei da Terra que transformava a terra em mercadoria, já prevendo a abolição e impedindo que o futuro ex-escravo tivesse livre acesso à terra.

A questão agrária no Brasil vai sendo empurrada ano após ano. Sabemos que o país tem tanta terra que se fosse distribuísse um lote de terra - o que não é a minha proposta - para todas as famílias de semterra no Brasil, ainda sobraria terra improdutiva. Mas, por que não é distribuída? Porque essa terra é transformada em capital, e voltando ao começo da minha falação, capital é aquilo que se usa para transformar em mais capital, e não para atender as necessidades humanas. É por isso que o MST está sendo criminalizado no Brasil. Não é porque eles são ensandecidos, não é porque eles não têm uma boa política educacional. Têm sim, as escolas deles funcionam, os trabalhos comunitários deles funcionam. Na periferia de São Paulo, nos bairros desindustrializados, nas cidades da Grande São Paulo, levaram as crianças para uma fazenda na cidade de Porto Feliz e, em vinte dias, as mudanças para melhor foram imensas: todas elas foram vacinadas, as que estavam em idade escolar foram matriculadas nas escolas de Porto Feliz, e já havia começado a funcionar uma escolinha dentro do acampamento. Por que a polícia expulsou-os de lá? Numa região onde os proprietários não pagavam os direitos trabalhistas há muito tempo, não pagavam empréstimos feitos com juros de pai para filho pelo Banco do Brasil. O MST naquela região incomoda os interesses do capital local. Assim, essas pessoas que estavam 
lá querendo viver foram criminalizadas e obrigadas a ir para a beira de uma estrada. Aqui no Paraná parece que a situação está bem pior na relação entre o Estado e alguns acampamentos do MST.

Mas não é só no Brasil que esses movimentos mais contestatórios começam a renascer ou voltam a renascer. No México também, como eu já citei, onde há o movimento de Chiapas. Onde mais? No Paraguai, na Bolívia e em vários países da América Latina. E na Europa também. Um dos movimentos mais extraordinários surgidos na Europa, nos últimos tempos, foi aquela marcha internacional contra o desemprego. Em nossa revista Lutas Sociais 4 tivemos a oportunidade de publicar um artigo de um francês, Christophe Aguiton, um dos líderes daquelas marchas internacionais contra o desemprego. $\mathrm{O}$ artigo dele é fascinante, na medida em que este movimento contra o desemprego é um movimento internacional, anti-racista, o que na Europa é extremamente importante. Trata-se de um movimento que conta com poucos recursos, muito pouco burocratizado, extremamente democrático, e conseguiu um impacto de caráter internacional, tanto que agora já existe a perspectiva de criar um novo encontro internacional juntando movimentos novos, novíssimos, no caso, movimentos sociais da América Latina e da Europa. Provavelmente haja um encontro dessa natureza em Belém do Pará e, mais para frente, na Europa. É sempre bom estar atento a esses movimentos. Era isso que eu queria trazer para vocês para debate: um pouco de crítica, um pouco de amargura, um pouco de teoria, mas um pouco de esperança também. Obrigado.

\section{RESUMO}

Os objetivos centrais desta conferência estão calcados em duas direções: analisar os movimentos sociais a partir da noção de modo de produção capitalista e, rever, criticamente, os conceitos difundidos por vários autores dos "novos" movimentos sociais, demonstrando as insuficiências teóricas que balizaram as suas análises. Nesse sentido, aponta para o fato de que, enquanto alguns movimentos sociais lutavam exclusivamente por cidadania, outros propunham o rompimento com o Estado capitalista.

Palavras-chave: movimentos sociais; cidadania; modo de produção capitalista; proletarização. 


\section{ABSTRACT}

The central objectives of this conference follow two directions: to analyse the social movements in the light of the notion of the capitalist mode of production, and to critically review the concepts of "new" social movements spread by many authors, showing the theoretical insufficiencies that guided their analyses. In this sense, it points to the fact that, while some social movements struggled solely for citizenship, others proposed the rupture with the capitalist State.

Key words: social movements; citizenship; capitalist mode of production; proletarization.

Lúcio Flávio Rodrigues de Almeida é professor de Ciência Política da PUC-SP e coordenador do Núcleo de Estudos de Ideologias e Lutas Sociais da Faculdade de Ciências Sociais e do Programa de Estudos Pós-Graduados em Ciências Sociais da PUC-SP. 